\title{
Verification of the Abbott Alinity m Resp-4-Plex Assay for detection of SARS-CoV-2, influenza $\mathbf{A} / \mathbf{B}$, and respiratory syncytial virus
}

Running Title: Verification of Alinity m Resp-4-Plex Assay

word count abstract: 115

word count manuscript: 2,556

Annie Cheng ${ }^{\text {a }}$, Stefan Riedel, ${ }^{\text {a,b }}$ Ramy Arnaout ${ }^{\text {a,b,c }}$, James E. Kirby, ${ }^{\text {a,b, }}$

${ }^{\mathrm{a}}$ Department of Pathology, Beth Israel Deaconess Medical Center, Boston, MA, USA

${ }^{\mathrm{b}}$ Harvard Medical School, Boston, MA, USA

${ }^{c}$ Division of Clinical Informatics, Department of Medicine, Beth Israel Deaconess Medical Center, Boston, MA USA 02215

${ }^{\#}$ Corresponding Author

James E. Kirby

Beth Israel Deaconess Medical Center

330 Brookline Avenue - YA309

Boston, MA 02215

jekirby@bidmc.harvard.edu

Phone: 617-667-3648

Fax: 617-667-4533 


\section{Abstract}

2 COVID-19 symptomology may overlap with other circulating respiratory viruses that may also

3 cause severe disease and for which there are specific and potentially life-saving treatments. The

4 Abbott Alinity m Resp-4-Plex assay is a multiplex PCR assay that simultaneously detects and

5 differentiates infection with SARS-CoV-2, influenza A, influenza B, and respiratory syncytial

6 virus (RSV). We characterized its accuracy, precision, and analytical sensitivity. All were found

7 to be robust for measures examined. In the context of sample-to-answer, near random access

8 automation on the Alinity m platform, we believe that the Resp-4-Plex assay offers significant

9 utility in addressing the current needs of the SARS-CoV-2 pandemic and future needs during

10 anticipated endemic circulation of SARS-CoV-2 with other respiratory viruses.

\section{Keywords}

13 SARS-CoV-2, influenza, respiratory syncytial virus, multiplex, nucleic acid amplification 14 technology, molecular diagnostics 
medRxiv preprint doi: https://doi.org/10.1101/2021.04.22.21255133; this version posted April 22, 2021. The copyright holder for this preprint (which was not certified by peer review) is the author/funder, who has granted medRxiv a license to display the preprint in perpetuity. It is made available under a CC-BY-NC-ND 4.0 International license .

\section{Introduction}

SARS-CoV-2, influenza A/B, and RSV may cause respiratory infection with significant morbidity and mortality. Respiratory disease signs and symptoms for these viruses overlap, and,

18 therefore, it is not possible to reliably differentiate between them on clinical grounds alone,

19 especially early during the course of disease. SARS-CoV-2 and influenza, especially, have

20 significant implications in terms of transmission inside and outside of hospital settings and

21 therefore require reliable methods for diagnosis. RSV, although primarily thought of as a serious

22 pathogen in young children, can also cause bronchiolitis and pneumonia in adults. Depending on

23 the stage of illness, there are therapeutics with varying efficacy for SARS-CoV-2, influenza, and

24 RSV. Therefore, sensitive detection and differentiation of these viruses are valuable clinical

25 determinations.

With social distancing and masking during the COVID pandemic, the circulation of

27 influenza and other respiratory viruses almost ceased in many locations (1). Presumably,

28 however, with less than $100 \%$ vaccine efficacy for influenza, waning immunity to circulating

29 respiratory viruses over a large population cohort, and reopening of our societies, circulation of

30 influenza and RSV will rebound and likely exceed normal levels for some time (2). At the same

31 time, SARS-CoV-2 will likely become endemic, potentially adopting a seasonal cycle with

32 enhanced transmission during the winter as observed in the United States during the winters of

332020 and 2021 (3). It will therefore be critical to be able to test both patients and staff for high

34 consequence respiratory pathogens to avert potential nosocomial transmission and to identify the

35 most advantageous therapeutic options for patients with serious illness. 
medRxiv preprint doi: https://doi.org/10.1101/2021.04.22.21255133; this version posted April 22, 2021. The copyright holder for this preprint (which was not certified by peer review) is the author/funder, who has granted medRxiv a license to display the preprint in perpetuity. It is made available under a CC-BY-NC-ND 4.0 International license .

A multiplex testing option for high consequence testing options would address these

37 specific diagnostic needs. The Abbott Alinity m Resp-4-Plex assay in March 2021 received

38 emergency use authorization designation for detection of SARS-CoV-2, influenza A, influenza B

39 and RSV. Approved sample types are either a nasopharyngeal swab collected by a health care

40 provider or a nasal swab specimen self-collected in a healthcare setting. The multiplex, reverse-

41 transcription real-time PCR assay targets the RdRp and N genes of SARS-CoV2: the matrix gene

42 of influenza A; the nonstructural 1 gene of influenza B, and the matrix gene of RSV. An internal

43 control is spiked into each sample in the form of armored RNA encoding a segment of the

44 hydroxypyruvate reductase gene from the pumpkin plant, Cucurbita pepo. It controls for

45 appropriate extraction and amplification in each reaction. Each amplicon is detected by a real-

46 time probe with a distinct fluorophore with the exception that both probes for the SARS-CoV-2

47 targets are detected with the same fluorophore. The primers and probes for the SARS-CoV-2

48 target are the same as those used in the singleplex Abbott RealTime SARS-CoV-2 and Alinity m

49 SARS-CoV-2 assays, whose performance characteristics have been examined in prior literature

50 (4-6). Cycle threshold numbers (Ct) determined on the Alinity m instrument in the Resp-4-Plex

51 assay are determined based on a fluorescence cutoff. They are used along with the inflection

52 point of the amplification curve at the maximum amplification efficiency (the max ratio) (7) for

53 qualitative assessment of target positivity and negativity (personal communication, Joshua

54 Kostera, Abbott Molecular).

Here we describe characterization of accuracy, precision, and limit of detection of the

56 Alinity m Resp-4-Plex assay determined as part of normal quality assurance activities prior to

57 adoption for clinical use in our clinical laboratory. 
medRxiv preprint doi: https://doi.org/10.1101/2021.04.22.21255133; this version posted April 22, 2021. The copyright holder for this preprint (which was not certified by peer review) is the author/funder, who has granted medRxiv a license to display the preprint in perpetuity.

It is made available under a CC-BY-NC-ND 4.0 International license .

Materials and Methods

60 Accuracy. Results from prior determinations either by Cepheid Xpert® Xpress Flu; direct

61 fluorescent antigen testing for influenza A/B, RSV, adenovirus, and parainfluenza 1, 2 and 3

62 and/or shell vial culture on R-Mix-Too monolayers (Quidel Corporation, San Diego, CA);

63 and/or reference laboratory testing at Eurofin ViraCor using the TEM-PCR assay (8) were

64 considered predicate comparator assays as enumerated. Samples were divided for Resp-4-Plex

65 testing on the two Alinity $m$ instruments at our institution. As there was no difference in

66 performance on these identical systems results are presented in aggregate. Discrepant resolution

67 included repeat testing of samples as available using Resp-4-Plex on the second Alinity $\mathrm{m}$

68 platform and/or using the Cepheid Xpert® Xpress SARS-CoV-2/Flu/RSV assay. Data for

69 individual sample is listed in Table S1.

71 Analytical sensitivity. For limit of detection studies, the AccuPlex SARS-CoV-2, Flu A/B and

72 RSV Verification Panel (catalogue \#0505-0183, LGC SeraCare, Milford, MA) with individual

73 members at defined equal concentrations, quantified by digital droplet PCR, were initially

74 diluted to $1 \mathrm{E} 4,5 \mathrm{E} 3,1 \mathrm{E} 3,5 \mathrm{E} 2,2 \mathrm{E} 2,1 \mathrm{E} 2,5 \mathrm{E} 1,2.5 \mathrm{E} 1,1 \mathrm{E} 1$ and $0.5 \mathrm{E} 1$ target amplicon genome

75 copies per $\mathrm{mL}$ and tested by Resp-4-Plex in quadruplicate. Each panel member consists of

76 either part or the entire genome of the target virus cloned into a replication incompetent Sindbis

77 virus. The Sindbis virus is an enveloped, single-stranded, RNA genome virus that serves as a

78 surrogate and control for all processes in the assay including extraction. The linearity of

79 amplification of each assay was determined by least squares linear regression based on $\mathrm{Ct}$

80 values obtained from each screening concentration, and PCR efficiency was determined using

81 slope of the regression line using the ThermoFisher calculator: 
medRxiv preprint doi: https://doi.org/10.1101/2021.04.22.21255133; this version posted April 22, 2021. The copyright holder for this preprint (which was not certified by peer review) is the author/funder, who has granted medRxiv a license to display the preprint in perpetuity.

It is made available under a CC-BY-NC-ND 4.0 International license .

82 https://www.thermofisher.com/us/en/home/brands/thermo-scientific/molecular-

83 biology/molecular-biology-learning-center/molecular-biology-resource-library/thermo-

84 scientific-web-tools/qpcr-efficiency-calculator.html. Three dilutions bracketing the potential

85 limit of detection cutoff were tested again with twenty replicates each to establish the LoD for

86 each analyte. The $95 \%$ detection threshold and confidence intervals were extrapolated by

87 Logistic regression in Prism 9 for MacOS (GraphPad, San Diego, CA). LoD analysis was only

88 performed on a single Alinity m instrument.

89

90 Results

91 Accuracy

92 To determine accuracy, the Resp-4-Plex assay was run using clinical samples that were

93 previously determined to be positive for the constituent viruses. Ten samples previously

94 determined to be SARS-CoV-2 positive using the Alinity m SARS-CoV-2 singleplex assay

95 were tested using Resp-4-Plex. All were positive for SARS-CoV-2. Although the Ct values for

96 SARS-CoV-2 on Resp-4-Plex were a mean -1.81 +/- 0.58 lower than fractional cycle numbers

97 on the singleplex assay, the assays were highly correlated with one another $\left(\mathrm{R}^{2}=0.99\right)($ Fig

98 1A).

99 Twelve samples previously determined to be influenza A positive by Cepheid Xpress

100 Flu were tested using Resp-4-Plex. All tested positive influenza A. A single sample tested with

101 Resp-4-Plex also yielded a positive RSV result with a high Ct value of 32.46 (see limit of 102 detection analysis below). The test was repeated using Resp-4-Plex on the second Alinity m 
medRxiv preprint doi: https://doi.org/10.1101/2021.04.22.21255133; this version posted April 22, 2021. The copyright holder for this preprint (which was not certified by peer review) is the author/funder, who has granted medRxiv a license to display the preprint in perpetuity. It is made available under a CC-BY-NC-ND 4.0 International license.

103 instrument and gave qualitatively and quantitatively almost identical results. The sample was 104 then tested using the Cepheid Xpress SARS-CoV-2/Flu/RSV assay and was influenza A 105 positive, RSV negative. This sample was interpreted as a potential Xpress RSV false negative 106 based on low viral load.

Ten samples previously determined to be influenza B positive using the Cepheid Xpress

108 Flu assay were tested using Resp-4-Plex. All tested positive for influenza B. A single sample

109 tested with Resp-4-Plex also yield a positive RSV result. The test was repeated using Resp-4-

110 Plex on the second Alinity m instrument and gave similar results. The sample was then tested

111 using the Cepheid Xpress SARS-CoV-2/Flu/RSV assay and was influenza B positive, RSV 112 positive. This sample was resolved as an influenza B/RSV true positive.

113 Ten samples previously determined to be RSV positive using a combination of direct 114 fluorescence antigen testing and/or shell vial culture and a single sample determined to be RSV 115 positive by TEM-PCR were tested using Resp-4-Plex. All were positive for RSV.

117 antigen testing and/or shell vial culture, five of which were also negative by TEM-PCR, were 118 tested using Resp-4-Plex. Sixteen samples were negative for the viruses detected by Resp-4119 Plex. One sample tested with Resp-4-Plex yield as positive result for influenza B with a high Ct 120 value of 34.2. The test was repeated using Resp-4-Plex on the second Alinity m instrument and 121 gave similar results. The sample was then tested using the Cepheid Xpress SARS-CoV122 2/Flu/RSV assay and was influenza B positive. A second sample (also negative by TEM-PCR) 123 yielded a positive result for influenza A with Resp-4-Plex with a high Ct value of 36.53 and a 124 positive result for RSV with a lower $\mathrm{Ct}$ value of 21.82. The test was repeated using Resp-4-Plex 125 on the second Alinity $\mathrm{m}$ instrument and gave similar results. The sample was then tested using 
medRxiv preprint doi: https://doi.org/10.1101/2021.04.22.21255133; this version posted April 22, 2021. The copyright holder for this preprint (which was not certified by peer review) is the author/funder, who has granted medRxiv a license to display the preprint in perpetuity.

It is made available under a CC-BY-NC-ND 4.0 International license .

126 the Cepheid Xpress SARS-CoV-2/Flu/RSV assay and was influenza A negative (however, with

127 a $\mathrm{Ct}$ value of 38.6) and RSV positive (Ct value of 23.4). The sample was resolved as likely true

128 positive on Resp-4-Plex for influenza A and RSV.

129 Six samples positive for Adenovirus or Parainfluenza virus 1, 2, or 3 by direct

130 fluorescent antigen testing, one sample positive for parainfluenza, two samples positive for

131 adenovirus or parainfluenza virus by shell vial culture, 1 sample positive for enterovirus by

132 TEM-PCR and three samples positive for low pathogenicity coronaviruses by TEM-PCR were

133 tested using Resp-4-Plex. All samples were negative for the viruses detected by Resp-4-Plex.

\section{Analytical Sensitivity}

For SARS-CoV-2, the LoD screen demonstrated excellent linearity with $\mathrm{R}^{2}=0.98$ and a

137 97\% PCR efficiency (Fig. 1B). The manufacturer's claimed LoD was confirmed through twenty

138 replicates at 50, 25 and 10 copies/mL using the SeraCare reference material, yielding 100\%,

$139100 \%$ and $80 \%$ detection, respectively. The LoD was therefore $<=25$ copies per $\mathrm{mL}$ with an $\mathrm{Ct}$

140 value of $35.72+/-0.54$ at 25 copies/mL. The logistic regression was non-convergent and

141 therefore an extrapolated LoD could not be established.

142 For influenza A, the LoD screen demonstrated excellent linearity with $\mathrm{R}^{2}=0.97$ and

143 93\% PCR efficiency. The manufacturer's claimed LoD was confirmed through twenty

144 replicates at 50, 25 and 10 copies/mL using the SeraCare reference material,yielding 100\%,

$14580 \%$ and $30 \%$ detection, respectively. The LoD was therefore $<=$ to 50 copies per $\mathrm{mL}$ with an

$146 \mathrm{Ct}$ value of $37.18+/-0.67$ at 50 copies/mL. By logistic regression, the LoD was 47 copies $/ \mathrm{mL}$

147 (95\% confidence interval $\sim 25-125$ copies $/ \mathrm{mL})$.

148 For influenza B, the LoD screen demonstrated excellent linearity with an $\mathrm{R}^{2}=0.97$ and a 
medRxiv preprint doi: https://doi.org/10.1101/2021.04.22.21255133; this version posted April 22, 2021. The copyright holder for this preprint (which was not certified by peer review) is the author/funder, who has granted medRxiv a license to display the preprint in perpetuity.

It is made available under a CC-BY-NC-ND 4.0 International license .

$149101 \%$ PCR efficiency. The manufacturer's claimed LoD was confirmed through twenty

150 replicates at 50, 25 and 10 copies/mL using the SeraCare reference material, yielding 100\%,

$15190 \%$ and $70 \%$ detection, respectively. The LoD was therefore $<=$ to 50 copies per $\mathrm{mL}$ with an

$152 \mathrm{Ct}$ value of $35.94+/-0.73$ at 50 copies/mL. By logistic regression, the LoD was 36 copies $/ \mathrm{mL}$

153 (95\% confidence interval $\sim 18-178$ copies $/ \mathrm{mL})$.

154 For RSV, the LoD screen demonstrated excellent linearity with an $\mathrm{R}^{2}=0.97$ and $97 \%$

155 PCR efficiency. The manufacturer's claimed LoD was confirmed through twenty replicates at 15650,25 and 10 copies/mL using the SeraCare reference material, yielding 100\%, 90\% and 75\%

157 detection, respectively. The LoD was $<=$ to 50 copies per $\mathrm{mL}$ with an $\mathrm{Ct}$ value of $35.75+/-0.70$

158 at 50 copies/mL. By logistic regression the LoD was 39.8 copies/mL (95\% confidence interval

$159 \sim 18-1000$ copies/mL).

161 Precision

Intra-run precision was determined by using pooled samples, positive for each of the

163 four viruses, and a negative pool. Each pool was tested in quadruplicate on each of the two

164 Alinity $m$ instruments with each individual test for each specific virus performed on each of the

165 Assay Processing Units (APU) \#1 through \#4 on each instrument, so that every APU was tested

166 during the precision testing. Inter-run precision was verified by testing the pools for each virus

167 on each alinity $\mathrm{m}$ instrument again on additional two separate days. Qualitative intra-run and

168 inter-run precision results were $100 \%$ correlated as expected.

Although Resp-4-Plex is a qualitative assay, we also assessed quantitative precision by

170 comparison of $\mathrm{Ct}$ values in replicates. Coefficients of variation $(\mathrm{CV})$ varied from 0.6 to $2.5 \%$

171 across all viruses tested on both instruments in intra-run precision comparisons and from $0.4 \%$ 
medRxiv preprint doi: https://doi.org/10.1101/2021.04.22.21255133; this version posted April 22, 2021. The copyright holder for this preprint (which was not certified by peer review) is the author/funder, who has granted medRxiv a license to display the preprint in perpetuity.

It is made available under a CC-BY-NC-ND 4.0 International license .

172 to $2.9 \%$ in inter-run precision comparisons. The precision of the $\mathrm{Ct}$ values for positive controls

173 run during the validation on Alinity $m \# 1(n=4)$ and Alinity $m \# 2(n=5)$ instruments, run once

174 per day of testing, was also examined. C.V.'s on individual instruments for each assay were all

175 less than $1 \%$. There was no statistical difference between the positive control $\mathrm{Ct}$ values run on

176 Alinity \#1 and Alinity \#2 for the four viruses (Fig. 1C), with significance considered $P<=0.05$,

177 with comparisons performed using the Kruskall-Wallis test. Therefore, reproducibility of both

178 instruments appeared essentially identical for the Resp-4-Plex assay.

\section{Discussion}

The Resp-4-Plex assay is welcome addition to targeted respiratory panel options that

182 will be necessary in a post-COVID world. It appeared highly accurate, sensitive, and precise.

183 The three descrepancies with comparator methods, specifically detection of co-infections, could

184 be attributed to enhanced detection by Resp-4-Plex. This was because: (1) the second virus was

185 detected on repeat testing by Resp-4-Plex on a second Alinity m platform, (2) the second virus

186 was detected by the alternative Cepheid respiratory panel, and/or (3) the second virus had a

187 very high $\mathrm{Ct}$ value, near its limit of detection, and therefore plausibly may have been below the

188 limit of detection of the comparator assays. Overall, our experience was consistent with

189 qualitative detection data described in the EUA product insert, although our data set was

190 significantly smaller in size.

Notably, the LoD for each individual virus was robust with high amplification

192 efficiencies even in the context of a multiplex assay and testing of quality control material in

193 which all four targets were present in equivalent amounts. In fact, the limit of detection for 
medRxiv preprint doi: https://doi.org/10.1101/2021.04.22.21255133; this version posted April 22, 2021. The copyright holder for this preprint (which was not certified by peer review) is the author/funder, who has granted medRxiv a license to display the preprint in perpetuity. It is made available under a CC-BY-NC-ND 4.0 International license .

194 SARS-CoV-2 in Resp-4-Plex ( 25 copies/mL) was below that determined in our analysis of the 195 SARS-CoV-2 SinglePlex assay ( 50 copies/mL, data not shown). The multiplex and singleplex 196 SARS-CoV-2 assays were also extremely well correlated $\left(\mathrm{R}^{2}=0.99\right)$. Furthermore, the $\mathrm{Ct}$ values were also log-linearly correlated with the quantitative 198 standard at and above the limit of detection of the assays with excellent PCR efficiencies. 199 Notably, Ct values or their equivalent (e.g. fractional cycle number (7)) may vary significantly 200 between platforms at the same viral load level and for difference viruses (9). Furthermore, they 201 vary inversely with viral load which is intuitively confusing to end users. We ultimately believe 202 that SARS-CoV-2 results should be reported selectively as a viral load, as most intuitively 203 understood by clinicians, benchmarked against a universal standard (6). In particular, there are 204 several situations where viral load values are helpful, for example, to distinguish between 205 reinfection versus persistent low levels of mRNA that may last months after a prior infection, 206 and to evalute likely infectivity in the appropriate contexts. The log-linear performance of the 207 Resp-4-Plex assays suggest that future conversion to a quantitative readout, i.e., a viral load, 208 should easily be supported and we believe will provide additional utility for patient 209 management. Furthermore, our previous study with the Abbott RealTime SARS-CoV-2 assay 210 (6) and the singleplex Alinity m SARS-CoV-2 assay (data not shown) supports a method for

211 accurately calculating the viral load from $\mathrm{Ct}$ measurements without the absolute need for a 212 standard curve, and/or extending viral load determinations beyond limits of available calibrator 213 material. Taken together, we verified the performance characteristis of a new molecular multiplex 215 respiratory panel assay on the Alinity m molecular system.. This platform notably provides high 216 throughput; sample-to-answer, random access and semi-batch functionality with a 115 minute 
medRxiv preprint doi: https://doi.org/10.1101/2021.04.22.21255133; this version posted April 22, 2021. The copyright holder for this preprint (which was not certified by peer review) is the author/funder, who has granted medRxiv a license to display the preprint in perpetuity.

It is made available under a CC-BY-NC-ND 4.0 International license .

217 sample to answer turn around time for prioritized specimens; and an ability to load and perform

218 multiple different tests at one time. We believe this assay and platform will be especially useful

219 in fulfilling future needs, in situations where SARS-CoV-2, influenza A, influenza B and RSV

220 circulate at significant levels, and where these viruses need to be detected and differentiated for

221 optimal patient management.

222

223 Acknowledgements

224 We thank the Abbott Molecular Group for providing test reagents and LGC SeraCare control

225 material for this work under a COVID-19 Diagnostics Evaluation Agreement. RA was a

226 recipient of grant support from Abbott Molecular under a clinical study agreement. 
medRxiv preprint doi: https://doi.org/10.1101/2021.04.22.21255133; this version posted April 22, 2021. The copyright holder for this preprint (which was not certified by peer review) is the author/funder, who has granted medRxiv a license to display the preprint in perpetuity. It is made available under a CC-BY-NC-ND 4.0 International license .

\section{References}

229 1. Olsen SJ, Azziz-Baumgartner E, Budd AP, Brammer L, Sullivan S, Pineda RF, Cohen C, Fry AM. 2020. Decreased Influenza Activity During the COVID-19 Pandemic - United

2. Baker RE, Park SW, Yang W, Vecchi GA, Metcalf CJE, Grenfell BT. 2020. The impact of COVID-19 nonpharmaceutical interventions on the future dynamics of endemic

3. Byun WS, Heo SW, Jo G, Kim JW, Kim S, Lee S, Park HE, Baek JH. 2021. Is

4. Hirschhorn JW, Kegl A, Dickerson T, Glen WB, Jr., Xu G, Alden J, Nolte FS. 2021. and Alinity m Systems. J Clin Microbiol doi:10.1128/jcm.03119-20.

243 5. Smith KP, Cheng A, Chopelas A, DuBois-Coyne S, Mezghani I, Rodriguez S, Talay M, SARS-CoV-2 PCR testing in a multi-hospital healthcare network during the COVID-19

247 6. Arnaout R, Lee RA, Lee GR, Callahan C, Cheng A, Yen CF, Smith KP, Arora R, Kirby 
medRxiv preprint doi: https://doi.org/10.1101/2021.04.22.21255133; this version posted April 22, 2021. The copyright holder for this preprint (which was not certified by peer review) is the author/funder, who has granted medRxiv a license to display the preprint in perpetuity. It is made available under a CC-BY-NC-ND 4.0 International license .

2507 Shain EB, Clemens JM. 2008. A new method for robust quantitative and qualitative $251 \quad$ analysis of real-time PCR. Nucleic Acids Res 36:e91.

252 8. Han J, Swan DC, Smith SJ, Lum SH, Sefers SE, Unger ER, Tang Y-W. 2006.

253 Simultaneous Amplification and Identification of 25 Human Papillomavirus Types with

254 Templex Technology. Journal of Clinical Microbiology 44:4157-4162.

255 9. Binnicker MJ. 2020. Challenges and Controversies to Testing for COVID-19. Journal of $256 \quad$ Clinical Microbiology 58:e01695-20. 
medRxiv preprint doi: https://doi.org/10.1101/2021.04.22.21255133; this version posted April 22, 2021. The copyright holder for this preprint (which was not certified by peer review) is the author/funder, who has granted medRxiv a license to display the preprint in perpetuity. It is made available under a CC-BY-NC-ND 4.0 International license .

\section{Author Contribution Statement.}

259 Annie Cheng conceptualized and performed experiments. Stefan Riedel reviewed and edited

260 manuscript and aided in formal analysis. Ramy Arnaout reviewed and edited the manuscript and

261 aided in formal analysis. James Kirby wrote the initial manuscript draft and aided in 262 conceptualization and formal analysis. 


\section{Figure Legend}

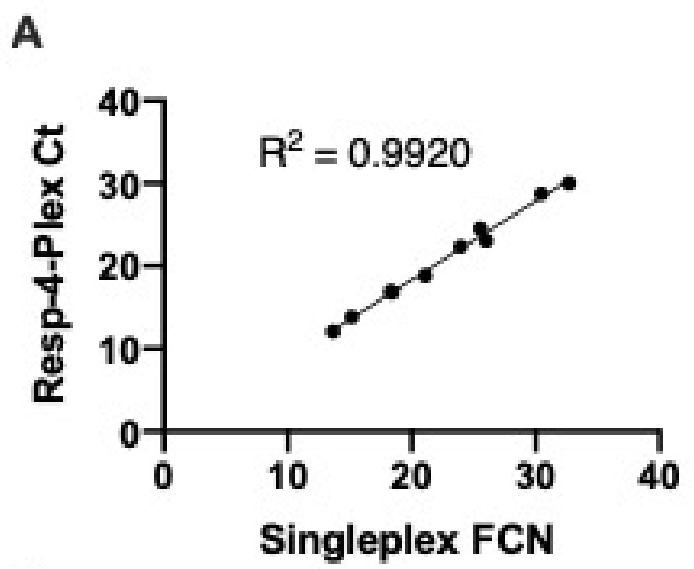

B

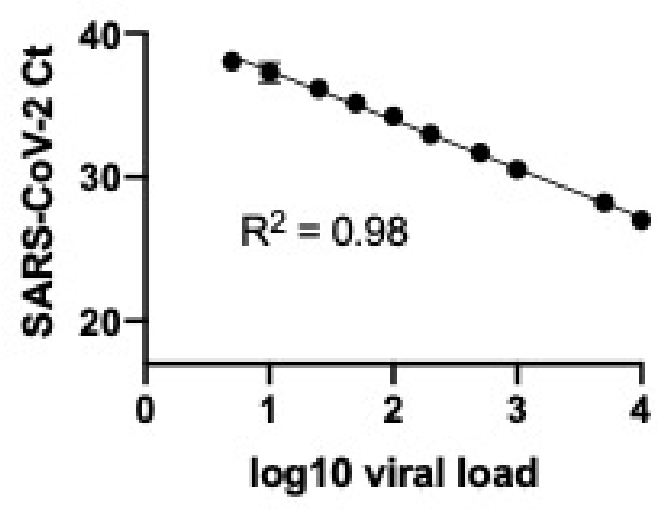

C
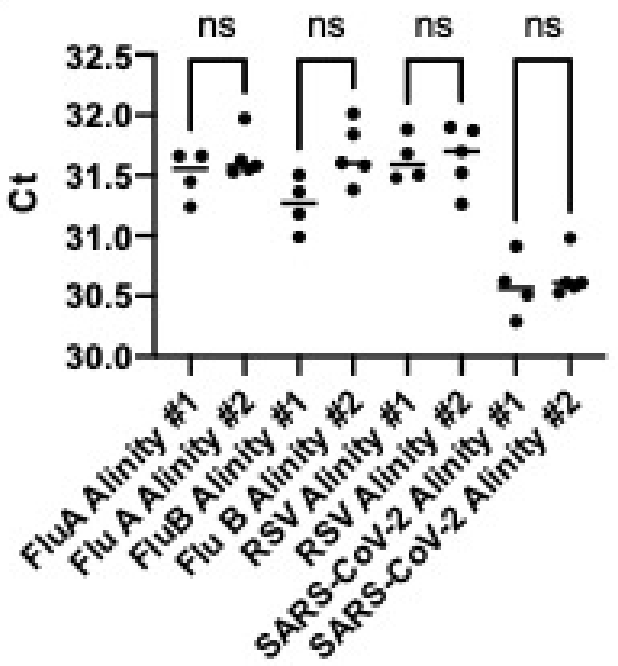

Figure 1. Performance of the Resp-4-Plex Assay. (A) Cycle threshold $(\mathrm{Ct})$ results from the SARS-CoV-2 test in the Alinity m Resp-4-Plex multiplex assay and fractional cycle numbers (FCN) (7) from the Alinity m SARS-CoV-2 singleplex assay were highly correlated when testing patient samples spanning the analytical measurement range of these tests. Amplification of the SARS-CoV-2 targets in the Resp-4-Plex assay was log-linear when examined in the range at and above the limit of detection. Data points shown are the mean and standard deviation of $\mathrm{Ct}$ values for 4 replicate measurements. (C) Data points for positive control $\mathrm{Ct}$ values for each individual assay in Resp-4-Plex, tested on four to five separate days on two separate Alinity instruments, were highly correlated and not statistically (n.s.) different between instruments. 
A

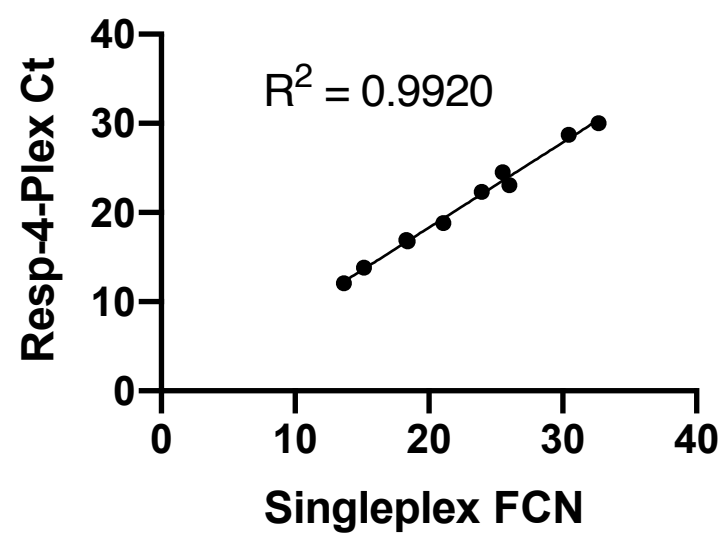

B

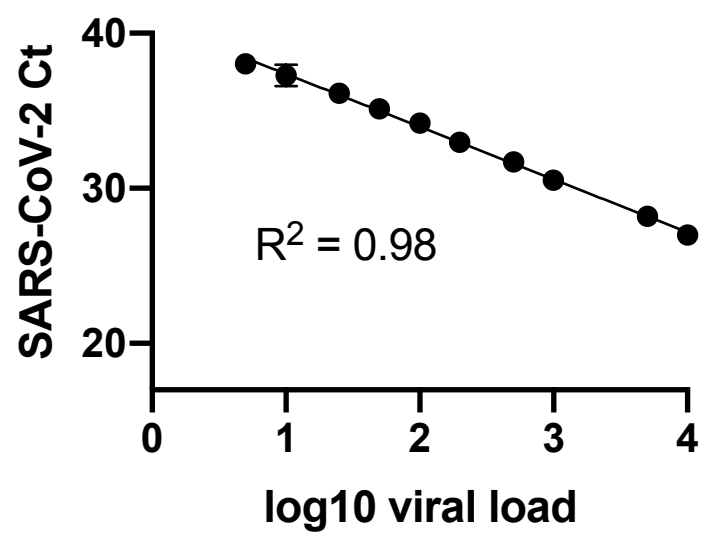

C
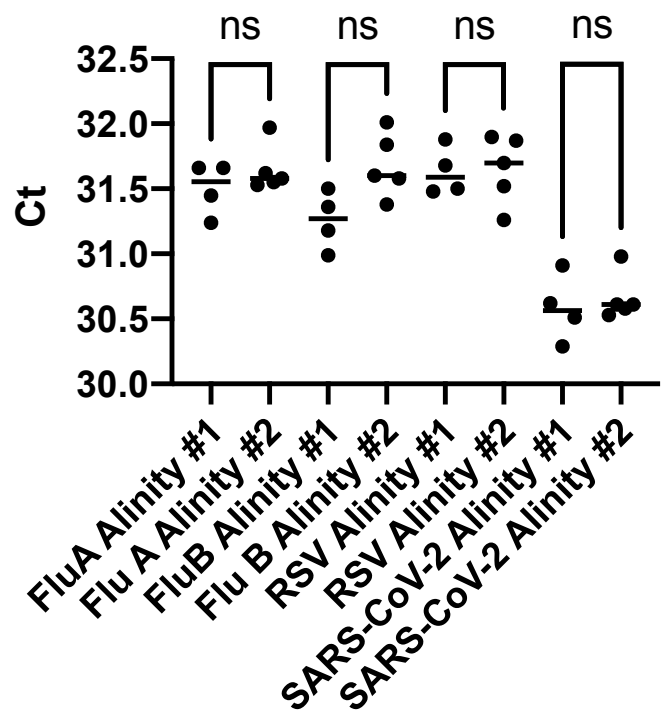